原著

\title{
若年者からの抜去小臼柬における小窩裂溝の 初期滴蝕について*
}

\author{
白 戸 勝 芳**
}

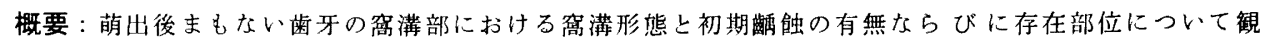
察し哽蝕の初発部位を推定しょうとした。

$8 \sim 15$ 歳の歯列稫正患者より抜去した臨床的に健全又は着色程度で電気抵抗值 $600 \mathrm{~K} \Omega$ 以上を示す上下

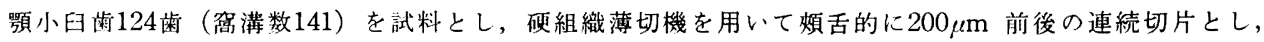

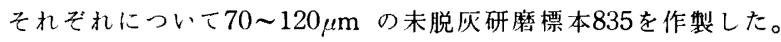

生: 物顕微鏡, 偏光䫓微鏡ならびに超軟X線発生装犆で末脱死研磨標本を観察し，万能投影機を用いて 密渾部の形华計測を行い, 次の結果を得た。

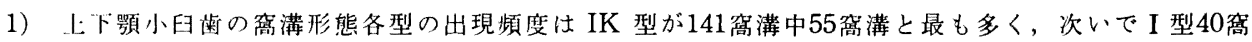

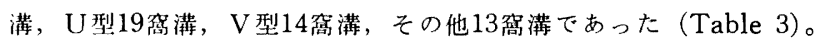

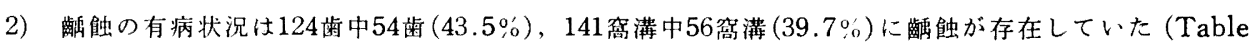
5)。

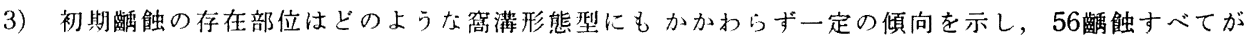

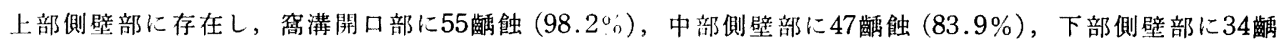

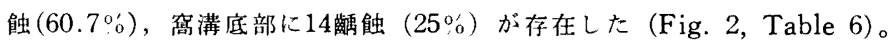

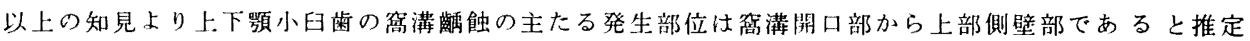
された。

\section{緒言}

臼歯の小窩裂溝（以下，窝溝と呼称）は踽触好発部位 として古くから重要視され，研究対象とされているが, 窩溝䀞蝕の初発部位については多様の報告があり, 必ず しも一致していない。Bödecker ${ }^{1)}$ (1928) は制強は窝溝 底部から初発すると云い，Gustafson²（1957）は常に窝 溝入口より初発するが䡌窩の形成は底部より始まると報 告し, Mortimer ${ }^{3)}$ (1964) は窩溝の側壁より初発すると


て意見が一致しない主な理由は須賀）(1978）が述べて いるように，䀞蝕の初期変化をとらえることがむずかし いためでもあ万うが, その他に研究対象である歯や研究
方法にも問題があると思わわる。

すなわち, 対象である歯が口腔に存在した期間の長 短, 歯種の相違, 蓇满開口部の定義の違い, 窩溝の連続 的観察の有無等である。

著者は萌出後まもない歯で, 肉眼的には, ほとんど健 全か軽い着色がある程度で, 榣蝕は存在したとしても初 期であると思われる㐘列矯正治療のために抜去された上 下頢小臼歯を研究対象とし, 連続研磨標本を作製, 窩溝 形態と蔃蝕の有無ならびに存在部位について観察し, 窩 溝激触の初発部位について検討を加えたので報告する。

\section{研究対象ならびに方法}

研究対象は $8 \sim 15$ 歳の61名（男子21名, 女子40名) か

* 本論文の要旨は第25回ならびに第27回口腔衛生学会総会において発表した。

** 東北大学歯学部予防㐘科学教室（指導：島田義弘教授）

* Department of Preventive Dentistry, Tohoku University School of Dentistry (Director: Prof. Yoshihiro SHIMADA)

詔和54年 7 月 11 日受付 
Table 1 Number of teeth studied by sex and age.

\begin{tabular}{l|l|l|l|l|l|l|r|r|r|r}
\hline \multirow{2}{*}{ Sex } & \multicolumn{10}{c}{ Age in years } \\
\cline { 2 - 11 } & 8 & 9 & 10 & 11 & 12 & 13 & 14 & 15 & Total \\
\hline Boys & 0 & 5 & 7 & 15 & 7 & 9 & 0 & 0 & 43 \\
Girls & 1 & 5 & 17 & 14 & 29 & 8 & 4 & 3 & 81 \\
\hline Total & 1 & 10 & 24 & 29 & 36 & 17 & 4 & 3 & 124
\end{tabular}

Table 2 Number of teeth studied by type.

\begin{tabular}{c|c|c|c|c|c}
\hline \multirow{2}{*}{ Jaw } & \multicolumn{5}{|c}{ Tpye } \\
\cline { 2 - 6 } & $\begin{array}{c}\text { Right } \\
\text { 2nd } \\
\text { bicuspid }\end{array}$ & $\begin{array}{c}\text { Right } \\
\text { 1 st } \\
\text { bicuspid }\end{array}$ & $\begin{array}{c}\text { Left } \\
1 \text { st } \\
\text { bicuspid }\end{array}$ & $\begin{array}{c}\text { Left } \\
2 \text { nd } \\
\text { bicuspid }\end{array}$ & Total \\
\hline Upper & 2 & 39 & 34 & 2 & 77 \\
Lower & 1 & 17 & 27 & 2 & 47 \\
\hline Total & 3 & 56 & 61 & 4 & 124
\end{tabular}

ら歯列矯正治療上の理由で抜去された上下顎小曰歯 124 歯である。肉眼的には, 鮫窩がなく, ほとんど健全で, 電気抵抗值 $600 \mathrm{~K} \Omega$ 以上であった窩溝である。その性別, 年齢別ならびに歯種別の歯数を Table 1，2 2 示した。 歯は抜去後, 可及的早期に 歯根部を生理食塩水に浸 し，歯冠部をパラフィンワックスで分離した後，気銃を 用いて入念に乾燥させた後に窩溝部のみを生理食塩水で ぬらし，歯牙電気抵抗計 MD-IR (日本光電社) を用い て窝溝部の抵抗值を測定した。引き続き肉眼ならびに実 体顕微鏡で観察したのち, 中性ホルマリンの10倍稀釈液 中に保存した。

約 1 カ月の後に歯を水洗し, アルコールで脱水, 樹脂 包埋し, 硬組織薄切機 (小松商事, Velnas Cut VA 201 型）を用いて煩舌的に $650 \mu \mathrm{m}$ 間隔で切断, $200 \mu \mathrm{m}$ 厚前 後の連続切片を得，それぞれを砥石で研磨して厚さ70 $120 \mu \mathrm{m}$ の未脱灰研磨標本835を作製した。

これらの標本について生物顕微鏡, 偏光顕微鏡, 超軟 $\mathrm{X}$ 線発生装置 (Softex, EMB 型ならびに CMR 型)を 用いて窝溝部における酶触の有無と存在部位を調べ, さ らに万能投影機 (Nikon, Model 6CT2) を用いて窩溝 の形態計測も行った。

尚, 窩溝数についてはその連接性 ${ }^{5,6)}$ の有無を標本で 観察し，124歯から分離独立した141窩溝を認め，それら の䆟满を構成する数枚の研磨標本のうち, 最も䆟溝の深 い標本の形態をその窝溝の代表標本として永野7) (1960) の方法に従って形態の分類を行った(Fig. 1)。

窨漊の計測は万能投影機に光電式マイクロメーターを
接続し, 窩满幅径 $200 \mu \mathrm{m}^{8)}$ の部位を窩溝開口部とみなし, 窝溝の深さと幅, 窩溝底エナメル質厚径, その他を計 測した。それらの計測点を窩溝の略図上で示したのが Fig. 2 である。

また，裇蝕の有無ならびに存在部位については，その 窩溝を形成する数枚の標本の生物顕微鏡所見, 偏光顕微 鏡所見（水封入, カナダバルサム封入）ならびに顕微 $\mathrm{X}$ 楾写真所見から総合的に判定したが有無の判定ができな かった例については畭蝕なしとした。

\section{研究成績}

I . 窩溝形態について

141の独立した窩溝について永野7)（1960）の形態分類 に従って上下䫟別に分類したのが Table 3 である。ま た，窩溝の深さ，窩溝開口部から $1 / 3$ ならびに $2 / 3$ の深 さにおける幅径ならびに窩溝底部の残存エナメル質厚径 について計測し，それぞれの窩溝形態型別の平均值と標 準誤差ならびに範囲を求め, それを示したのが Table 4 である。

Table 3 に示されるように，上下頡小臼歯間には窩 溝形態各型の出現頻度に著明な差がみられた。上䇗小臼 歯の窩溝は IK 型 $(51.9 \%)$ と I 型 $(32.5 \%)$ が多く, U型 $(12.0 \%)$ とV型 $(3.6 \%)$ は少なく，その他の分 類不能型は 1 例もなかった。一方, 下䫟小臼歯の窩溝は I 型 $(22.4 \%), \mathrm{IK}$ 型 $(20.7 \%), \mathrm{V}$ 型 $(19.0 \%), \mathrm{U}$ 型 (15.5\%) と 4 型の出現頻度に大差がなく, さらにその 他の分類不能型は $22.4 \%$ とかなり多かった。上下顎歯の 


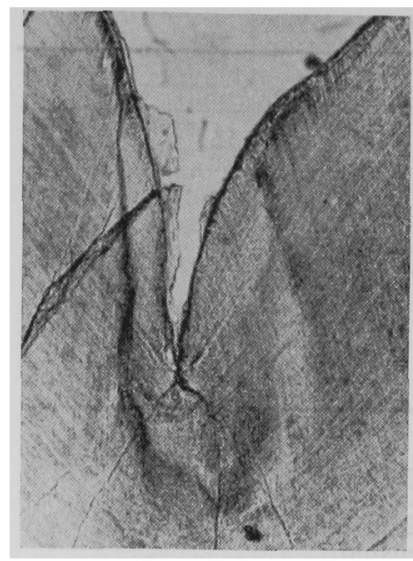

A



D

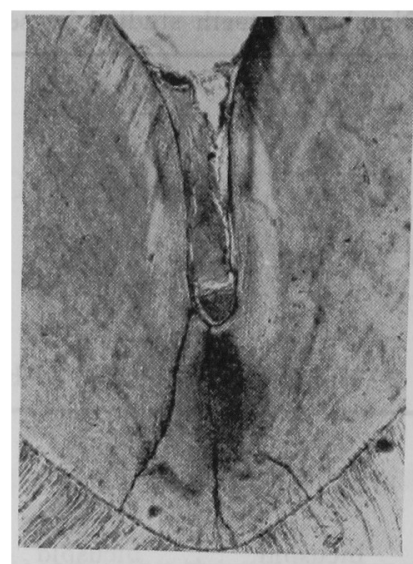

B



E

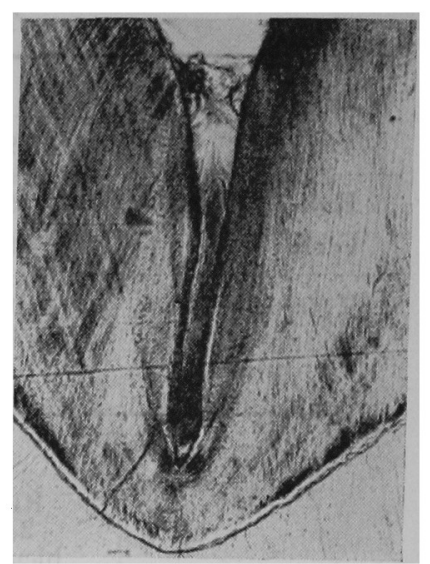

C
A V-type
B U-type
C I -type
D IK-type
E Other type

Fig. 1 Typical morphological types.

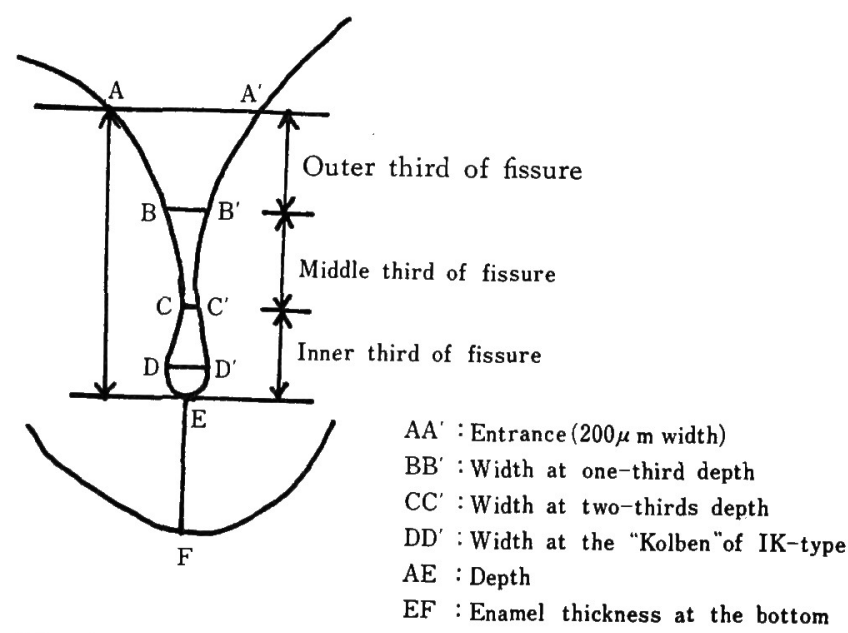

Fig. 2 Diagram showing the measured positions of a fissure. 
Table 3 Number of fissures classified by morphological characteristics.

\begin{tabular}{|c|c|c|c|c|c|c|}
\hline \multirow{2}{*}{ Type of tooth } & \multicolumn{6}{|c|}{ Morphological types } \\
\hline & $\begin{array}{c}\text { V-type } \\
(\%)\end{array}$ & $\begin{array}{c}\text { U-type } \\
(\%)\end{array}$ & $\begin{array}{c}\text { I-type } \\
(\%)\end{array}$ & $\begin{array}{c}\text { IK-type } \\
(\%)\end{array}$ & $\begin{array}{l}\text { Other types } \\
(\%)\end{array}$ & $\begin{array}{c}\text { Total } \\
(\%)\end{array}$ \\
\hline $\begin{array}{l}\text { Upper } \\
\text { bicuspids }\end{array}$ & $\begin{array}{c}3 \\
(3.6)\end{array}$ & $\begin{array}{c}10 \\
(12.0)\end{array}$ & $\begin{array}{c}27 \\
(32.5)\end{array}$ & $\begin{array}{c}43 \\
(51.9)\end{array}$ & $\begin{array}{c}0 \\
(0)\end{array}$ & $\begin{array}{c}83 \\
(100)\end{array}$ \\
\hline $\begin{array}{l}\text { Lower } \\
\text { bicuspids }\end{array}$ & $\begin{array}{c}11 \\
(19.0)\end{array}$ & $\begin{array}{c}9 \\
(15.5)\end{array}$ & $\begin{array}{c}13 \\
(22.4)\end{array}$ & $\begin{array}{c}12 \\
(20.7)\end{array}$ & $\begin{array}{c}13 \\
(22.4)\end{array}$ & $\begin{array}{c}58 \\
(100)\end{array}$ \\
\hline Total & $\begin{array}{l}14 \\
(9.9)\end{array}$ & $\begin{array}{c}19 \\
(13.5)\end{array}$ & $\begin{array}{c}40 \\
(28.4)\end{array}$ & $\begin{array}{c}55 \\
(39.0)\end{array}$ & $\begin{array}{l}13 \\
(9.2)\end{array}$ & $\begin{array}{c}141 \\
(100)\end{array}$ \\
\hline
\end{tabular}

Table 4 Mean and range obtained from the estimates of fissures.

\begin{tabular}{|c|c|c|c|c|c|c|c|c|c|}
\hline \multirow{2}{*}{$\begin{array}{l}\text { Morpho- } \\
\text { ogical } \\
\text { ypes }\end{array}$} & \multirow{2}{*}{$\begin{array}{l}\text { Number } \\
\text { of } \\
\text { fissures }\end{array}$} & \multicolumn{2}{|c|}{ Fissure $\operatorname{depth}(\mu \mathrm{m})$} & \multicolumn{2}{|c|}{$\begin{array}{l}\text { Width at one- } \\
\text { third depth } \\
\qquad(\mu \mathrm{m})\end{array}$} & \multicolumn{2}{|c|}{$\begin{array}{l}\text { Width at two- } \\
\text { thirds depth } \\
(\mu \mathrm{m})\end{array}$} & \multicolumn{2}{|c|}{$\begin{array}{l}\text { Remaining } \\
\text { enamel thickness } \\
\text { at the bottom }(\mu \mathrm{m})\end{array}$} \\
\hline & & $\begin{array}{l}\text { Mean } \\
\pm S . E .\end{array}$ & $\begin{array}{c}\text { Range } \\
\text { Min. } \sim \text { Max. }\end{array}$ & $\begin{array}{l}\text { Mean } \\
\pm \text { S.E. }\end{array}$ & $\begin{array}{l}\text { Range } \\
\text { Min. } \widetilde{M a x}\end{array}$ & $\begin{array}{l}\text { Mean } \\
\pm S . E .\end{array}$ & $\begin{array}{l}\text { Range } \\
\text { Min. } ~ \\
\text { Max. }\end{array}$ & $\begin{array}{l}\text { Mean } \\
\pm \text { S.E. }\end{array}$ & $\begin{array}{l}\text { Range } \\
\text { Min. } \sim \\
\text { Max. }\end{array}$ \\
\hline$J$-type & 14 & $\begin{array}{r}243.6 \\
\pm 38.4\end{array}$ & $35 \sim 626$ & $\begin{array}{r}117.0 \\
\pm \quad 6.6\end{array}$ & $78 \sim 167$ & $\begin{array}{r}79.3 \\
\pm \quad 6.4\end{array}$ & $46 \sim 116$ & $\begin{array}{r}604.5 \\
\pm 37.0\end{array}$ & $316 \sim 886$ \\
\hline J-type & 19 & $\begin{array}{r}417.6 \\
\pm 32.6\end{array}$ & $161 \sim 606$ & $\begin{array}{r}129.6 \\
\pm 10.6\end{array}$ & $76 \sim 222$ & $\begin{array}{r}112.8 \\
\pm 10.4\end{array}$ & $53 \sim 212$ & $\begin{array}{r}457.9 \\
\pm 47.5\end{array}$ & $75 \sim 971$ \\
\hline -type & 40 & $\begin{array}{r}925.2 \\
\pm 56.6\end{array}$ & $375 \sim 1896$ & $\begin{array}{r}65.4 \\
\pm 5.7\end{array}$ & $14 \sim 178$ & $\begin{array}{r}53.2 \\
\pm 5.3\end{array}$ & $15 \sim 188$ & $\begin{array}{r}288.2 \\
\pm 24.7\end{array}$ & $54 \sim 648$ \\
\hline K-type & 55 & $\begin{array}{r}820.7 \\
\pm 32.0\end{array}$ & $422 \sim 1569$ & $\begin{array}{r}58.8 \\
\pm \quad 3.9\end{array}$ & $22 \sim 137$ & $\begin{array}{r}65.2 \\
\pm 5.7\end{array}$ & $12 \sim 191$ & $\begin{array}{r}261.5 \\
\pm 23.4\end{array}$ & $55 \sim 1119$ \\
\hline $\begin{array}{l}\text { Jther } \\
\text { types }\end{array}$ & 13 & $\begin{array}{l}737.3^{1)} \\
\pm 76.9\end{array}$ & $271 \sim 1196^{1)}$ & $\begin{array}{c}117.1^{2)} \\
\pm 13.9\end{array}$ & $41 \sim 172^{2)}$ & $\begin{array}{l}135.1^{2)} \\
\pm 19.7\end{array}$ & $22 \sim 262^{2)}$ & $\begin{array}{r}282.0 \\
\pm 37.6\end{array}$ & $28 \sim 478$ \\
\hline Total & 141 & $\begin{array}{l}731.0^{3)} \\
\pm 29.4\end{array}$ & $35 \sim 1896^{3)}$ & $\begin{array}{c}80.9^{4)} \\
\pm 3.8\end{array}$ & $14 \sim 222^{4)}$ & $\begin{array}{c}75.1^{4)} \\
\pm 4.1\end{array}$ & $12 \sim 262^{4)}$ & $\begin{array}{r}362.0 \\
\pm 35.7\end{array}$ & $28 \sim 1119$ \\
\hline
\end{tabular}

1) 12 samples, 2) 11 samples, 3) 140 samples, 4) 139 samples

溝の合計では, 上頡歯の傾向を反映して IK 型が最も く, 次いで I 型, U型, $\mathrm{V}$ 型, その他の分類不能型の であった。

次に Table 4 から䆚溝形態型別の窩溝の深さと幅径 らびに简溝底部のエナメル質厚径を比較した。それぞ の型において最大值と最小值間に大きな差があり，か り大きなバラッキの存在を認めるが, 平均的には Fig. に示したように, 窩溝が浅く, 幅径が広くかつ窩溝底 のエナメル質の厚いのがV型とU型, 反対に窩溝が深

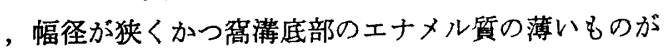
型と IK 型であった。また，すべての窝溝底部に必ず ナメル質が存在した。

II. 酹蝕の有病状況について

対象歯の窩菙は肉眼的にほとんど健全で $600 \mathrm{~K} \Omega$ 以上 電気抵抗值を示したもののみであったが，124歯中54

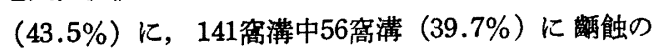
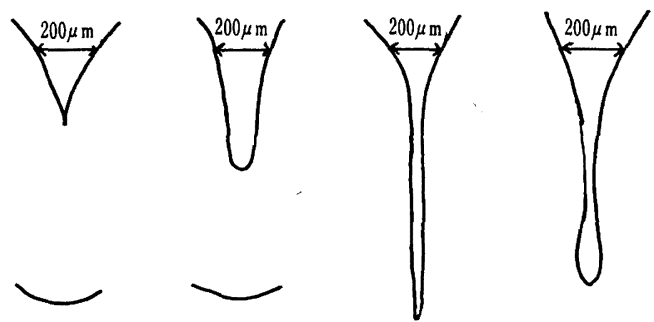

V-type

U-type



IK-type

Fig. 3 Diagrams showing average fissures obtained from morphometric values.

存在が認められた。

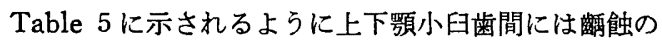
有病状況に著明な差がある。上䫑小曰歯では 83 窩溍中 48 
Table 5 . Prevalence of carious lesions in relation to the morphological types of fissures.

\begin{tabular}{|c|c|c|c|c|c|c|c|}
\hline & Carious or not & $\begin{array}{c}\text { V-type } \\
(\%)\end{array}$ & $\begin{array}{c}\text { U-type } \\
(\%)\end{array}$ & $\begin{array}{c}\text { I-type } \\
-(\%)\end{array}$ & $\begin{array}{c}\text { IK-type } \\
(\%)\end{array}$ & $\begin{array}{c}\text { Other types } \\
(\%)\end{array}$ & $\begin{array}{l}\text { Total } \\
(\%)\end{array}$ \\
\hline Upper & carious & 0 & 5 & 17 & 26 & 0 & $\begin{array}{c}48 \\
(57.8)\end{array}$ \\
\hline jaw & non-carious & 3 & 5 & 10 & 17 & 0 & $\begin{array}{c}35 \\
(42.2)\end{array}$ \\
\hline Lower & carious & 1 & 1 & 1 & 5 & 0 & $\begin{array}{c}8 \\
(13.8)\end{array}$ \\
\hline jaw & non-carious & 10 & 8 & 12 & 7 & 13 & $\begin{array}{c}50 \\
(86.2)\end{array}$ \\
\hline \multirow{2}{*}{ Bothe jaws } & carious & $\left(\begin{array}{c}1 \\
7.1)\end{array}\right.$ & $\begin{array}{c}6 \\
(31.6)\end{array}$ & $\begin{array}{l}18 \\
(45)\end{array}$ & $\begin{array}{c}31 \\
(56.4)\end{array}$ & $\begin{array}{c}0 \\
(0)\end{array}$ & $\begin{array}{c}56 \\
(39.7)\end{array}$ \\
\hline & non-carious & $\begin{array}{c}13 \\
(92.9)\end{array}$ & $\begin{array}{c}13 \\
(68.4)\end{array}$ & $\begin{array}{c}22 \\
(55)\end{array}$ & $\begin{array}{c}24 \\
(43.6)\end{array}$ & $\begin{array}{l}13 \\
(100)\end{array}$ & $\begin{array}{c}85 \\
(60.3)\end{array}$ \\
\hline
\end{tabular}

Table 6 Site of carious lesions in relation to the morphological types of fissures.

\begin{tabular}{c|c|c|c|c|c|c}
\hline $\begin{array}{c}\text { Morphological } \\
\text { types }\end{array}$ & $\begin{array}{c}\text { Number of } \\
\text { carious } \\
\text { fissures }\end{array}$ & Entrance & Outer third & Middle third & Inner third & Bottom \\
\hline V-type & 1 & 1 & 1 & 1 & 1 & 1 \\
U-type & 6 & 6 & 6 & 6 & 3 & 3 \\
I-type & 18 & 18 & 18 & 15 & 10 & 3 \\
IK-type & 31 & 30 & 31 & 25 & 20 & 7 \\
\hline $\begin{array}{c}\text { Total } \\
(\%)\end{array}$ & 56 & 55 & 56 & 47 & 34 & 14 \\
\hline
\end{tabular}


中 8 窝溝 $(13.8 \%)$ に㽀蝕が存在するにすぎなかった。

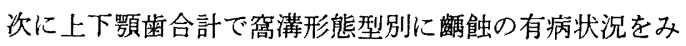

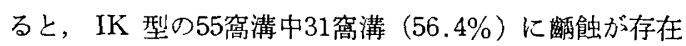

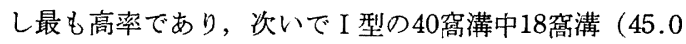

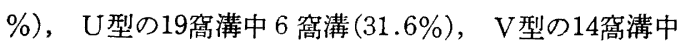
1 窩溝 $(7.1 \%)$ ， その他の分類不能型の 13 窩溝中 0 窝溝 ( 0 \%)の順であった。简溝が深く, 幅径の狭いIK 型, I 型が窝溝の浅く, 幅径が広いU型、V型よりも䠉強に なりやすい傾向が示された。

III. 䠔蝕の存在部位について

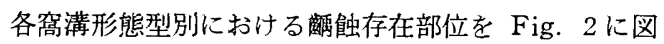
示した䆟溝開口部, 窝溝底部, 窩溝の深さに応じて 3 等 分した窝溝側壁部 (上部側壁部, 中部側壁部, 下部側壁 部）に分けて検討した結果を Table 6 に示した。

Table 6 に示したように被触の存在部位はどのような 倣溝形態型においても一定の傾向を示している。すなわ ち，56简满硒蝕はすべて上部側壁部を包含して存在して おり, 次いで窝溝開口部には55酮蝕 $(98.2 \%)$, 中部側壁

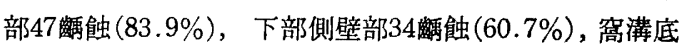

部にまで及んだものは14鹪蝕（25\%）であった（Fig. $4,5,6)$ 。

\section{考察}

\section{I 、窝溝形態について}

臼歯咬合面の窩溝の有無ならびに形態分類に関して数

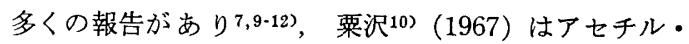
セルローズのフィルムを利用したレプリカ像で窩渋部を 観察し，上下䇗小臼歯には全く㸗溝は存在せず，すべて 正常な溝 (groove) で，上下䫓大臼歯においても数\%し か䆟溝はないと述べ, 他の研究者と異なる報告をしてい る。

一方, Galil ら ${ }^{11)}$ (1975) は vinyl resin replication technique を用いて立体的に窩满部を観察したところ，

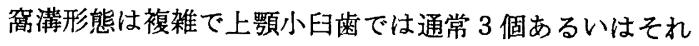
以上の pit からなる“a single straight fissure”で あり，下顎小臼歯では反対に“a curved fissure，"で 上下䫑大目歯は pit 数も多く, 加形態も多種多様に わたっていると述べ, 窩溝の存在を認め, しかも歯種間 の简溝形態の相違を報告している。 


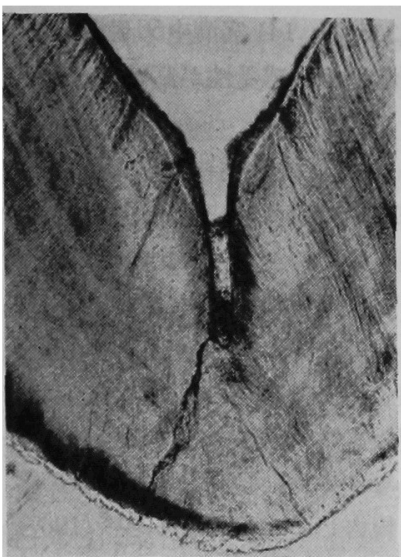

A

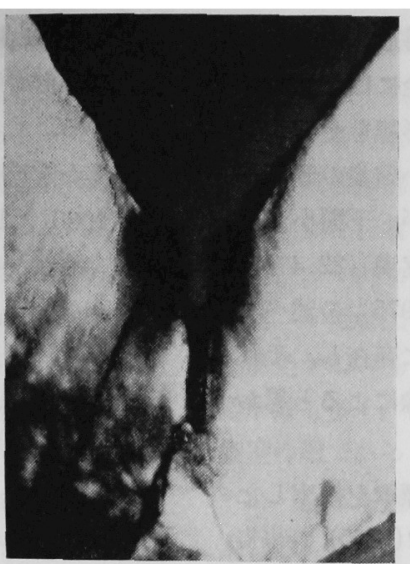

B

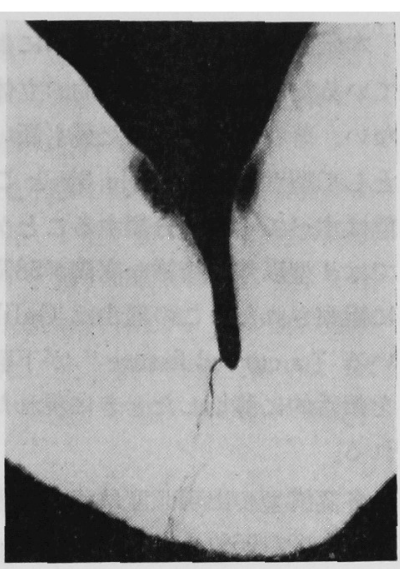

C

Fig. 4 One case of carious lesion located at the entrance and the outer third of a I-type fissure. In this and the following figures, photographs labeled A were taken with the light microscope, those labeled $\mathrm{B}$ were taken with the polarizing microscope, and those labeled $\mathrm{C}$ are microradiographs.

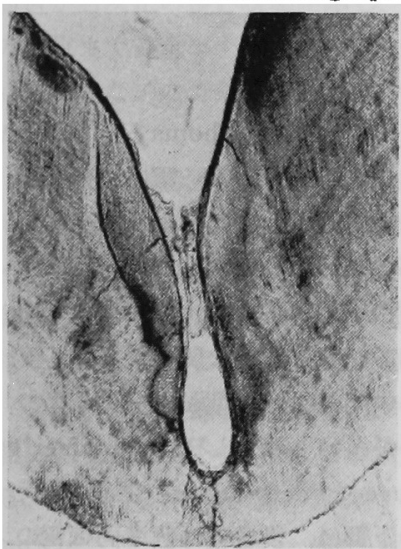

A

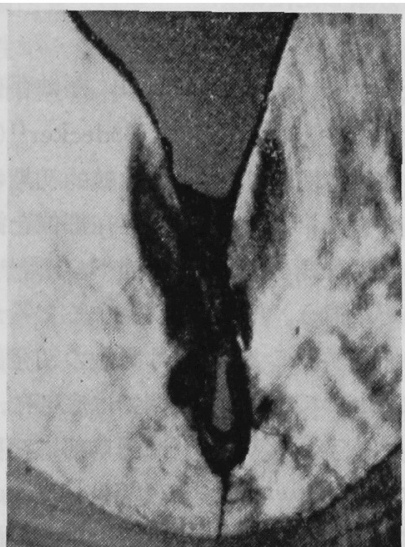

B



$\mathrm{C}$

Fig. 5 One case of carious lesion located between the entrance and the inner third of a IK-type fiissure.

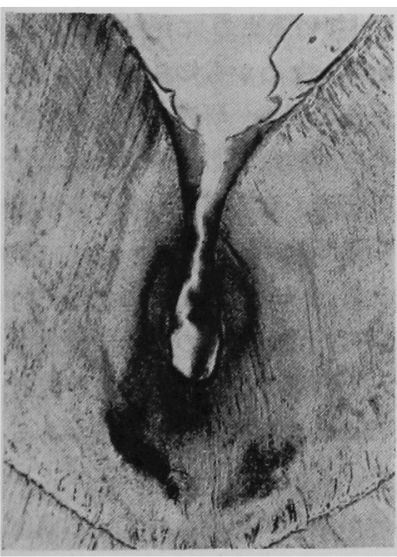

A

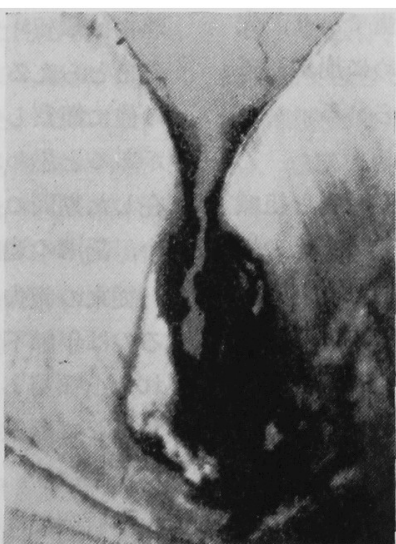

B

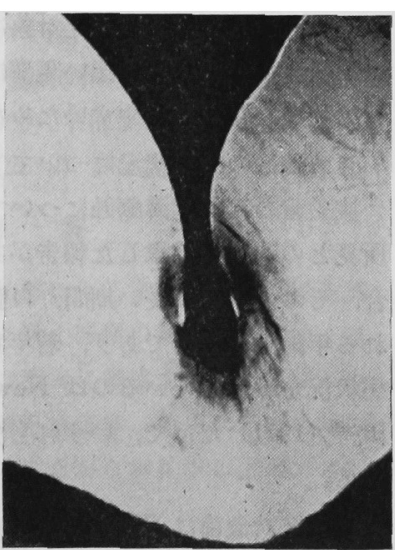

$\mathrm{C}$

Fig. 6 One case of carious lesion located between the outer third and the bottom of a IK-type fissure. 
本研究では未脱灰研磨標本により各窩漊形態を観察し ているために窩渾を連続的, 立体的に完全には把握でき ない。著者は観察できた最も深い窩溝の形態をその代表

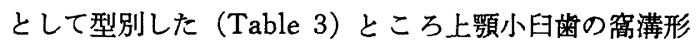
態はすべて 4 型に分類することができたが，下頻小臼歯

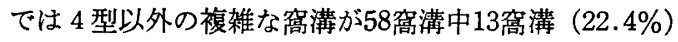
に観察された。この理由は Galil ら ${ }^{11)}(1975)$ の述べて いる“a curved fissure” が下䫑小臼歯に存在し，それ を㛲舌的に薄切したときに現れた複雑な像によると思わ れる。

各䆟溝型の出現頻度は歯の未脱灰研磨標本を観察した 倉橋ら ${ }^{122}$ (1959), 永野?)(1960), König ${ }^{13)}$ (1965) の報告 ではV型が最も多いと述べているが，本研究成績は彼ら の報告と一致せず，IK 型， I 型が多く存在した。この 主な理由は観察した歯種の相違の他に, 彼らは作成した 個々の未脱灰研磨標本ごとに窩溝形態を型分類したため もあろうと思われる。

上下頡小臼歯の窩溝部を計測した報告において，小 野14（1951）は㸗溝開口部の 平均幅径を $170 \mu \mathrm{m}$ とし,

Fejerskov ら ${ }^{8)}$ (1973)，Crabb9（1976）は窩满開口部 の幅径をそれぞれ $200 \mu \mathrm{m}, 250 \mu \mathrm{m}$ とし，それを基準点と して窩溝各部を計測している。このように窩满計測の場 合，開口部の計測点が報告者によってそれぞれ違う。そ の相違によって, ある程度の数值の差は当然生ずること になるが，本研究では既報者の中間的な数值として幅径 $200 \mu \mathrm{m}$ を採用し，この部位を窝溝開口部として窩溝の 計測を行った(Table 4)。窩溝の深さは最大値 $1896 \mu \mathrm{m}$ で Fejerskov ら ${ }^{8)}$ (1973）の報告よりやや大きく，窩溝 底エナメル質厚径は $28 \mu \mathrm{m}$ で Gillings ら ${ }^{15)}$ (1973) の 報告よりも小さかった。これは歯種の違いや人種差によ るむのもあろうが, 本研究対象は若年者の歯であり, 先 人の研究ではきわめて深い窩溝は鸼蝕のために崩壊して 研究対象から除かれやすいためなどが考えられる。

\section{II. 触蝕の有病状況について}

抜去歯の初期窝溝麜蝕について，その肉眼所見と組織 所見との関連を追求した報告があるが3,16-20)，多くの場 合，その対象歯は長い期間，口腔環境に存在したと思わ れる年齢不詳の歯であり，若年者の歯について，その有 病状況を報告しているのは Newbrun ら ${ }^{19)}$ (1959) と島 田 ${ }^{203}$ (1971) だけで，いずれも少数歯についての観察で ある。

本研究対象歯は萌出後まもなく，肉眼的に酩窩もな く,しかも鵖蝕になりにくい傾向があると考えられてい る $600 \mathrm{~K} \Omega$ 以上 ${ }^{211} の$ 電気抵抗值をもつ歯であるにもかか

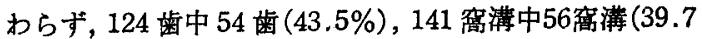

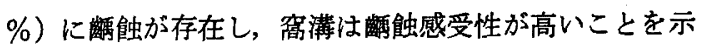
している。

同様な窩淟形態型別に 分類した 倉橋ら ${ }^{12)}$ (1959)，永 野7) (1960)，König ${ }^{13)}$ (1965) は歯種別，窩溝形態型別に 解蝕有病状況について報告していないので比較すること

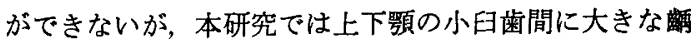
鳋有病状況の違いがみられ歯種間の酽触感受性の相違を

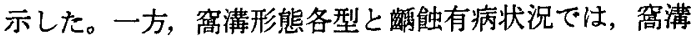
が深く幅径が狭い IK 型，I 型が窩溝が浅く幅径が広い U型，V型よりも䬱蝕になりやすい傾向を示し，浅い窩 溝が麆蝕になりやすいと報告しているZuhrt ら²2) (1967) と反対の結果を示し，窩溝形態の型と酥蝕感受性とに関 連があることを示唆している。又，その他の分類不能型

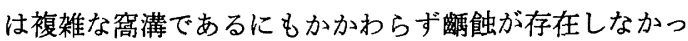
たことは部蝕感受性の低い下顎小臼歯であるためと思わ れる。

\section{III. 襧蝕存在部位について}

Bödecker ${ }^{1)}$ (1928), Boyle 23) (1955), Thoma ら ${ }^{24)}$ (1960)

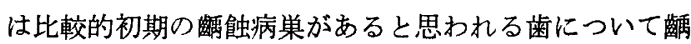
蝕存在部位を観察し, 窩溝嬏蝕は简溝底部より初発する と述べ, 小野14)(1951)，Gustafson ${ }^{22}$ (1957) は開口部より 初発すると考えている。永野7) (1960), Mortimer ${ }^{\text {8) (1964) }}$ は瞒蝕の初発部位は窩溝形態型と密接な関倸があり, V 型では底部に，U型では中間部に，I 型および IK 型で は開口部に初発するものが多いと報告し7), Mortimer ${ }^{3)}$ (1964) は shallow groove と deep fissure に分類し, 前者では窩溝両壁側部の下部に, 後者では窩瑇両壁側の 上部に初発すると報告している。

このように窝淦麜蝕の初発部位について意見が異なる 理由は須賀4) (1978）が述べているよ5に酩蝕の初期変 化をとらえることがむずかしいためかも知れないが，そ の他に観察している歯や用語の相違, 研究方法にも問題 があると思われる。すなわち, 対象である歯が口腔に存 在した期間の長短, 歯種の相違, 窩满開口部の定義の違 い, 窩溝の連続的観察の有無等である。

従来の報告のらち, これらの問題をかなり考虑してい るのは年齢不詳ではあるが歯列稪正治療のために抜去さ れた上領第 1 小臼歯10歯と下顎第 1 小四歯 2 歯を研究対 象として暗蝕を観察した König ${ }^{13)}$ (1965) の報告がある にすぎない。

本研究では抜歯時の年齢が確実に記録されている萌出 後まもない歯で肉眼的には汪とんど健全で $600 \mathrm{~K} \Omega$ 以上 の電気抵抗値を示している若年者の上下頭小曰歯を対象 
としているので檕蝕病変が存在した場合, その病変の経 過時間は萌出時からのごく短い期間と限定できるのでそ



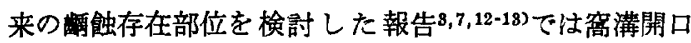
部の定義や窩潔壁の分割部位があいまいである。

触存在部位を各窩溝形態型別に検討した Table 6 によるとどのような窩湮形態型にもかかわらず一定の傾 向を示し, 56 解蝕はすべて上部側壁部に存在し, 次に窝溝 開口部 $(98.2 \%)$ ，中部側壁部 $(83.9 \%)$ ，下部側壁部 $(60.7$ $\%)$ ，窩洆底部 $(25 \%)$ であった。

禽满開口部が含まれていない1 酩蝕（Fig. 6）は10歳 男子の出で着色した裔溝を有し, その窩溝内容物は強固 に窝淦壁に付着している所見である。顕微X線写真所見 では開口部と決めた幅径 $200 \mu \mathrm{m}$ の部位まで明らかな脱 灰像はみられないが，未脱灰研磨標本観察では開口部 付近が石灰化の良い状態を示し，偏光顥微鏡所見ではそ の部位まで健全エナメル質と異なる複屈折性がみられる が明膫でないので辡蝕の存在部位として開口部を除外し た。

以上より窩溝麊蝕は窩溝全体に拡がりやすいけれど も, 醨蝕はすべて上部側壁部に存在し, 次に開口部に多

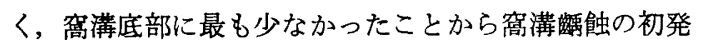
部位の多くは窝溝開口部に近い上部側壁部にあるためで はないかと推定した。

最近の走査型電子顕微鏡を用いて観察された窩满内容 物に関する新しい知見はこの推定を支持すると思われ る。すなわち,末萌出歯の窩满は ameloblast p enamel cuticle で充ちて扔り 25)，萌出後まもなく細菌が侵入す るがそれは窩溝開口部から中間部に密存在し26-28), 時 間の経過とともに窩溝底部に 石灰化した内容物がみら れ27)，古い歯では窩溝開口部にも石灰化した内容物がみ

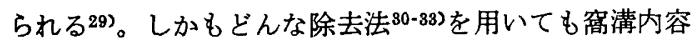
物を完全に除去できないこともわかってきた。このこと は窩淺底部はたとえ細菌が侵入したとしても細菌が存在 するのに必要な栄養源を口腔環境より摂取しくくい部位 であるばかりではなく，そこは窩溝内容物の石灰化が始 まりやすい部位なので必ずしも細菌の存在と増殖に好適 な部位でないことを意味していると思われる。

\section{結 論}

萌出後まもない歯牙の咬合面裔溝部における窩渾形態 と初期䴣蝕の有無ならびに存在部位を検索するため, 歯 列稪正治療上の理由で，抜去された上下頡小四歯124歯 （独立した䆟溝数141）について電気抵抗值を測定し,
未脱灰研磨標本835を作製, 生物䫓微鏡, 偏光顕微鏡, 超軟X線発生装置ならびに万能投影機を用いて観察なら びに計測を行ない，次の結果を得た。

1）裔溝形態の各型は上下顎小臼歯間に著明な差があ る。上顎小歯では IK 型, I 型が多く，その他の分類 不能型は 1 例もなかった。下䫕小歯では IK 型, I 型 U 型，V型の出現頻度に大差なかったが，その他の分類 不能型が $22.4 \%$ を存在した。上下䫑小臼歯全体では IK 型が最も多く, 次で I 型, U型, V型, その他の分類不 能型の順であった。

2）窝筂形態の各型の窩溝の深さ，開口部から $1 / 3$ お よび $2 / 8$ の媣さの幅径, 㸗淦底部エナメル質厚径の計測 值を比較すると窩溝が浅く, 幅径が広くかつ窩溝底エナ メル質の厚いものがV型，U型に，反対に窩溝が哚く， 幅径が狭くかつ窝溝底エナメル質が薄いものが I 型, IK 型になる傾向が強かった。

3）嗝蝕有病状況では124歯中54歯 (43.5\%)，141窩溝

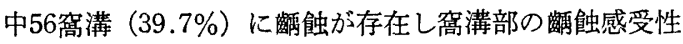
の高いことを示している。又, 上下顎小臼歯の比較では

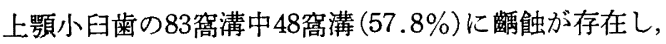

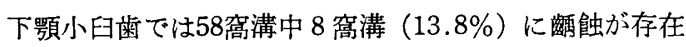
し，上下顎小田歯間の磻蝕感受性の違いを示した。

4) 酮蝕有病状況と窩溝形態各型との関係では IK 型 が55窝溝中31窩溝 $(56.4 \%)$ と最も多く袘蝕が存在し,

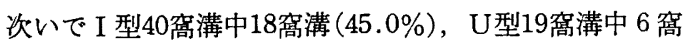

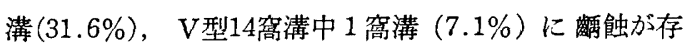
在したが，その他の分類不能型13窩溝には酽蝕が存在し なかった。窩溝が深く幅径が狭い IK 型, I 型が窩满が 浅く幅径が広いV型，U型よりも酩蝕になりやすい傾向 を示した。

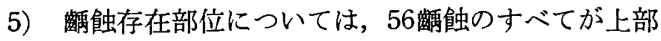
側壁部を包含して存在し，窩溝開口部に55雄蝕 $(98.2 \%)$ ，

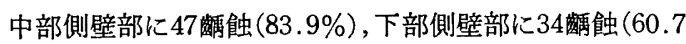
$\%)$ ，䆚满底部に14解触（25\%）が存在した。

\section{謝 辞}

稿を終るにあたり，終始想切なる御指導と御校閲を賜 わりました島田義弘教授に哚く感謝の意を捧げます。ま た，本研究の遂行と歯牙の蒐集に御協力いただきました 予防歯科学教室の皆様と歯科矮正学, 第一ならびに第二 口腔外科学教室の諸先生方に心から御礼申し上げます。

\section{文献}

1) Bödecker, C. F.: Differences in the penetration of dental caries on smooth and on 
grooved or pitted surfaces, Dental Items of Interest., 50; 7, 1928.

2) Gustafson, G. : The histopathology of caries of human dental enamel, Acta. Odont. Scand., $15 ; 13,1957$.

3) Mortimer, K. V.: Some histological features of fissure caries in enamel, Adv. Fluorine Res. Dent Caries Prev., 2; 85, 1964.

4) 須賀昭一：䀞触病理学研究の問題点（特にエナ

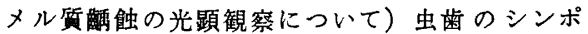
ジウム，歯苔とエナメル質のかかわり合い， 口 腔保健協会, 東京, 1978, 101頁.

5）黒須アイ子：小窝裂溝の連接状热につマて，日 歯保誌，2；76，1959.

6）角川進太郎：上頻第一大臼歯の初期践触に関す る研究（特に中心小㸗と遠心小窝を含む斜走隆 線部の連接状態について)，日歯保誌，14；161， 1972.

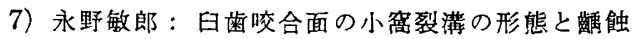
の初発部位との関係，歯科学報，60；1178， 1960.

8) Fejerskov, O., Melsen, B. and Karring, T. : Morphometric analysis of occlusal fissures in human premolars, Scand. J. dent. Res., 81 ; 505, 1973.

9) Crabb, H. S. M.: Fissures at risk, Brit. dent. J., $140 ; 303,1976$.

10）粟沢靖之: 酾触好発溝の形態学的再検討, 日大 歯学, $41 ; 653,1967$.

11) Galil, K. A. and Gwinnett, A. J. : Threedimentional replicas of pits and fissures in human teeth: Scanning electron microscopy study, Archs. Oral Biol., $20 ; 493,1975$.

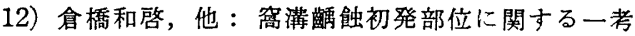
察, 歯科学報, 59 9 ; 51, 1959.

13) König, K. G. : Dental morphology in relation to caries resistance with special reference to fissures as susceptible areas, J. Dent. Res., 42 ; 461, 1963.

14）小野寅之助：婳触の初発部位と唃触成立後の進 行様相 (1), 現代の歯学, 3；1，1951.

15) Gillings, B. and Buonocore, M. : Thickness of enamel at the base of pits and fissures in human molars and bicuspids, J. Dent. Res., $40 ; 119,1961$.


困難性，歯界展望，10；219，1953.

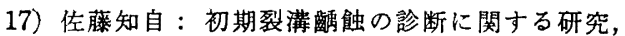
口腔衛生会誌，7；85, 1957.

18）島田義弘，他：小简裂淦鲖触の診断の困難性に
関する研究，口腔衛生会誌，8；165，1958.

19) Newbrun, E., Brudevold, F. and Mermagen, H. : A microradiographic evalution of occlusal fissures and grooves, J.A.D.A., 58 ; 26 , 1959.

20）島田義弘：集団における䀞蝕検出上の諸問題, 口腔衛生会誌, $20 ； 257,1971$.

21）黛 嘉泰：電気抵抗測定による小简裂鲜触の 診断法, 日菌保誌, 7；50, 1964.

22) Zuhrt, R. und Vierus, H.: Zur metrischen bestimmung und pathogenetischen bedeutung der fissurenformen, Stoma (Heidelb.), 20 ; 260, 1967.

23) Boyle, P. E. : Kronfeld's histology of the teeth and their surrounding structures, Lea and Febiger, Philadelphia, 1955, p. 132.

24) Thoma, K. H. and Goldman, H. M. : Oral pathology, C. V. Mosby Co., St. Louis, 1960, p. 334.

25) Galil, K. A. and Gwinnett, A. J.: Histology of fissures in human unerupted teeth, J. Dent. Res., $54: 960,1975$.

26) Galil, K. A. and Gwinnett, A. J. : Human tooth fissure contents and their progressive mineratization, Archs. Oral Biol., 20 ; 559, 1975.

27) Buonocore, M. G.: The use of adhesives in dentistry, Charles C Thomas, Springfield, 1975 , p. 107.

28) Galil, K. A. and Gwinnett, A. J. : Scanning electron microscopy: Observations on occlusal human dental plaque, J. Canad. Dent. Ass., 39 ; 472, 1973.

29) Ooya, K. : A scanning electron microscopic study on the differences between newly erupted teeth and old teeth with reference to fissure enamel surfaces and contents, Bull. Tokyo Med. Dent. Univ., 24 ; 89, 1977.

30) Tayler, C. L. and Gwinnett, A. J. : A study of the penetration of sealants into pits and fissures, J.A.D.A., 87 ; 1181, 1973.

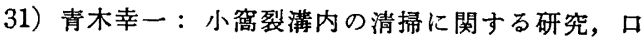
病誌, $41 ; 225,1974$.

32）青木幸一：小露裂渾内の清掃に関する研究一清 㡏能率向上のためのチップ改良一，口病誌，42； $257,1975$.

33）川上進：小曧裂淦封鎖材に関する基䂢的研究 （1）小简裂溸清掃法，および sealant の浸入性 と裂溝部エナメル表層の脱灰性について, 日歯 保誌，20；287， 1977. 


\section{Abstract: Incipient Fissure Caries in Extracted Premolar Teeth from Young Orthodontic} Patients, Katsuyoshi SHIROTO*. This study was undertaken to find the relationship between the morphological characteristics of fissures and the prevalence and the extent of initial caries and to deduce the site of caries attack in the fissures of premolars extracted from orthodontic patients. The teeth were 124 premolars which appeared clinically sound, extracted from 61 children aged 8 to 15 years, and having electrical resistance values of above $600 \mathrm{~K} \Omega$. Vertical bucco-lingual serial ground sections were prepared from each tooth and 835 sections were obtained.

The sections were observed by light and polarizing microscopy and by microradiography, and the size of fissures was measured using a profile projector.

The following results were obtained.

1. In the frequency of morphological characteristics, IK-type of fissures were 55, I-type 40, U-type 19, V-type 14, and other types 13 (Table 3).

2. In the prevalence of carious lesions, carious teeth were 54 out of $124(43.5 \%)$, and carious fissures were 56 out of $141(39.7 \%$ ) (Table 5).

3. Regardless of morphological characteristics, all sites of carious lesions showed the same tendency : $56(100 \%)$ were found at the outer third of the fissure, $55(98.2 \%)$ at the fissure entrance, $47(83.9 \%)$ at the middle third of the fissure, $34(60.7 \%)$ at the inner third of the fissure, and $14(25 \%)$ at the bottom of the fissure (Fig. 2, Table 6). From these findings, it was assumed that the main site of caries attack was probably at the outer third of the fissures. 